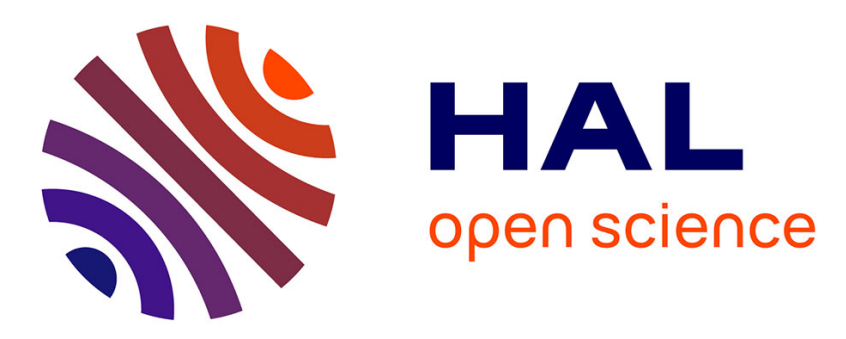

\title{
Geovisualizing the sail-to-steam transition through vessel movement data
}

Mattia Bunel, F. Bahoken, César Ducruet, Claire Lagesse, Bruno Marnot, Eric Mermet, Séléna Petit

\section{- To cite this version:}

Mattia Bunel, F. Bahoken, César Ducruet, Claire Lagesse, Bruno Marnot, et al.. Geovisualizing the sail-to-steam transition through vessel movement data. Ducruet C. Advances in Shipping Data Analysis and Modeling. Tracking and Mapping Maritime Flows in the Age of Big Data, Routledge, pp.189-205, 2017, Routledge Studies in Transport Analysis, 9781138280939. hal-01623631v2

\section{HAL Id: hal-01623631 \\ https://hal.science/hal-01623631v2}

Submitted on 12 Nov 2021

HAL is a multi-disciplinary open access archive for the deposit and dissemination of scientific research documents, whether they are published or not. The documents may come from teaching and research institutions in France or abroad, or from public or private research centers.
L'archive ouverte pluridisciplinaire HAL, est destinée au dépôt et à la diffusion de documents scientifiques de niveau recherche, publiés ou non, émanant des établissements d'enseignement et de recherche français ou étrangers, des laboratoires publics ou privés. 


\section{Geovisualizing the sail-to-steam transition based on vessel movement data}

Mattia BUNEL, Françoise BAHOKEN, César DUCRUET, Claire LAGESSE, Bruno MARNOT, Eric MERMET, Séléna PETIT

Pre-final version of the chapter published in Ducruet C. (Ed.) (2017) Advances in Shipping Data Analysis and Modeling. Tracking and Mapping Maritime Flows in the Age of Big Data, Routledge Studies in Transport Analysis, pp. 189-205.

Despite the crucial importance of maritime transport for world trade and economic development, dedicated tools to map the evolution of vessel movements remain lacking. Such movements, especially those recorded by the maritime insurance company Lloyd's List, represent the only available information documenting the changing spatial distribution of the world's shipping routes in the last century or so. This chapter tackles the lacuna head on by discussing how this particular type of shipping data can be accurately represented on a map (see Chapter 1 for a review of the field). Such an exercise poses specific issues in terms of geovisualization, as it necessitates, among other developments, the creation of a virtual maritime grid to which port nodes and their mutual vessel flows are assigned. Beyond geomatics, this research is also an opportunity to shed new light on a vibrant research question in maritime history, namely how steam has replaced sail shipping in space and time. We extracted snapshots of global maritime flows every five years from the Lloyd's Shipping Index between 1890 and 1925 in order to test the capacity of the geoportal to visualize such flows, and at the same time verify the spatio-temporal evolution of a bi-layered maritime network. The remainder of this chapter is organized as follows: the next section discusses the scarcity of maritime data cartography until recent years in the light of general knowledge on flow mapping in geography and elsewhere. It is followed by a description of how vessel movement data had been incorporated into a dedicated visualization system. Lastly, it provides the first-ever cartographies of such movements while discussing the gaps between our results and the existing literature on the transition from sail to steam shipping. Conclusions point to a number of ways how the visualization system may be improved in the future, and how it can contribute toward addressing numerous other issues in global transport studies in general. 


\section{The cartography of spatial maritime flows}

\section{Theoretical issues}

Flow mapping consists in representing over a given space, often geographic (i.e. generally based on a continuous vision of proximities between places, such as kilometers), a link-node diagram where the nodes are the origin and destination places and the link their (weighted) relation. In other words, flow mapping is a form of graph spatialization across a geometric space $(x, y)$ where the positions of nodes are constrained by a force-directed function. Thus, the choice of the quasi-metric is not of first importance because i) spatial considerations are often ignored in Social Network Analyses and theory; and ii) the aim of the figure is to focus more on the easier perception of the relationships (weighted or not) between nodes than their position. In doing that, the method aims to reduce links' cross effects and repositioning nodes; the latter being often shifted to deliver an aesthetical figure of the whole system.

Therefore, in opposition to flow mapping, spatial movements necessitate a broader reflection on the cartographic process of the so-called flow maps. Spatial transfers generally called movements, currents, or flows - correspond to a changing position in a spatiotemporal framework, a shift between two places represented on the map by a direct link. Weighted links characterize flows designed by lines, directed or not. Such links belong to a (spatial) planar graph, when the transport infrastructure that supports movement is well known, for a specific mode like roads, but then it does not translate a flow per se. Otherwise it is non-planar. Whatever the nature of the graph, the semiotic approach of flow mapping consists in a variation of the width of the line as underlined by earlier engineers such as Harness (1837) Minard (1845) and then Bertin (1967), with reference to basic principles of graphical semiology (especially the visual variable of size). Mapping a movement instead of a flow leads then to a similar approach, but fundamentally differs in terms of semantics (Bahoken, 2016). The main difference between the two approaches is the greater importance given to spatial interaction in the first case in terms of both the analysis and the interpretation of the map. Such issues have great implications in terms of semantics, database construction, and flow measurement, especially in terms of the importance given to the cartographic background (Goodchild et al., 2007). The length of the link itself is an essential component of its understanding in addition to its volume; in other words, the travelled cartographic distance (Bahoken, 2016). Length and width are thus two essential components of the cartography of any transfer across space. However, while Bahoken (2016) introduced the cartographic distance in flow and movements mapping, the perspective emerged in the early 1970s with pioneering discussions on the concept of graphic distance (Tobler, 1979; Müller, 1979), later followed by L'Hostis (1997) for the construction of network maps. Such advances were a response to previous theoretical 
research on transport development and the revolution of speed (Bretagnolle, 2009). An increasing number of maps were produced by modifying the position of places rather than the statistical information behind the flows. Examples include vector anamorphic maps (unipolar and multipolar) allowing the use of real instead of Euclidean metrics; they are also known as isochronic maps, where the "...symbolic representation expresses the time factor, through the overlap of lines sharing equal transport time, speed, or accessibility" (Bretagnolle, 2005, p. 56).

In such a context, the French geographer Bertin (1973, p. 345) provided an example that justifies the decomposition of the numeric information before mapping. As underlined by the author: "it is not sufficient to trace the real itineraries to represent a system of relations. A map of shipping lanes, even weighted, does not show the commercial function of activity centers. It shows the density of ships on the sea. The diversity, weight, and directionality of commercial maritime relations between European and Mediterranean cities only appear when each relation, albeit maritime, is represented by a straight line" (Bertin, 1973, p. 344). Despite the impossibility of answering such questions directly, what becomes clear is the complementarity (Bahoken, 2016, p. 172-173) between their movement mapping (top) and flow mapping (bottom), taking into account that topographic constraint leads to map movement and not just simple flows or relations. Here, the territorial space is not a simple layout for aesthetical aims; it has a strong influence on the graphic aspects of the design of such flows, but also on their semantic aspects in a theoretical framework, in that it considers the role of distance frictions and spatial detours in the mapping process (L'Hostis, 2015), in addition to the numerical modelling.

\section{The specifics of maritime flows}

While the cartography of shipping data evolved considerably over the last century (see Chapter 1), subsequent cartographies grew scarce and tended to ignoring space and the connected territories in their focus on graph topology. From the early 2000s, maritime flow maps were characterized by various levels of data aggregation, from the space-time trajectory of individual vessels (Buard et al., 2015; Etienne et al., 2015) to the network of inter-port linkages and the intercontinental trunk lines, often resulting in density maps (or heatmaps) using various techniques of which spatial interpolation or grid mapping. Most of the time, such works represent straight O-D lines without paying much attention to weight, space, distance and detours. The geographic background often remains a simple support eluding the numerous topographical constraints mentioned above, especially on a world scale. Because maritime flows occur across the sea or ocean space, namely, a continuous surface limited by coastlines, and remain bound to ports situated at the sea-land interface, 
their visualization remains somewhat fuzzy (Rodrigue et al., 2013) and it is particularly difficult to avoid crossing continents (Grataloup, 2011). In addition, "the straight line between two points across the ocean is rarely [never?] the fastest route for commercial vessels" (Galton, cited in Bretagnolle, 2005).

Whatever their resolution and scale, maritime flows are necessarily situated on the ocean space -namely, a continuous area limited by coastlines and directed towards the ports. This constraint is specific to maritime flows, being a non-planar network constrained by physical space much more than airlines, for instance. Not taking into account such a geographic dimension thus leads to unrealistic maps (Bahoken et al., 2016). The Euclidian logic of classic flow mapping inevitably makes maritime flows cross continents by means of more or less curved, directed or weighted lines. In other transport sectors, flows are attributed to physical infrastructures (road, railway, river...) or cross continents without causing major distortions of reality (airlines, telecommunications). In addition, maritime flows overcome additional constraints such as the location of ports, the natural conditions for navigation (straits, ice), and other economic or political barriers. Throughout the last decade however, data-related solutions for visualization have grown apace in relation to shipping. As described and explained in Chapter 1 by Ducruet about existing geovisualization portals from the private or academic world, such solutions often remain limited when it comes to data sources, analytical tools, and time coverage.

\section{Lloyd's List as a source to measure global sail and steam traffic}

Throughout the history of literature on global shipping, a vast majority of works had documented the emergence of steam navigation from its early days (i.e. 1820s), due to the enormous consequences of such a technological innovation for world trade. Yet, there remains considerable debate among scholars about the pace and the geography of the transition from sail to steam. In their synthetic work, Williams and Armstrong (2012) underline another transition, namely, from the subjective self-confidence of early historians, who took for granted the rapid and overwhelming domination of steam over sail, to the more objective and critical contributions of other scholars from the 1950s onwards, which moderated the manner in which the technological transition truly occurred. In addition and based on a largely untapped data source on shipping movements at British ports between 1853 and 1910, Williams and Armstrong (2012) proposed a quantitative analysis to tackle this debate. One of the ambitions of this chapter is to go one step further by placing the latter study in the light of a new spatio-temporal perspective. In fact, the results of Williams and Armstrong (2012), which will be discussed below in more detail, only reflect British port traffic, thereby causing a bias in their effort to extrapolate the observed trends to the rest of 
the world. What remains lacking is a global approach that would take into account all world ports and further insist on the local and regional differences of this technological transition.

Despite its episodic recognition by scholars throughout maritime studies as a whole, the Lloyd's List corpus -and in particular the Shipping Index- is the only source capable of documenting the movements of merchant vessels globally and back in time (see Ducruet et al., 2015 for a detailed description of this corpus). We extracted vessel movement data every 5 years between 1890 and 1925, the period that marks the demise of sail shipping. The year 1890 was chosen because that is when the Shipping Index starts to cover not only British but all vessels. It also marks the decisive progress of propulsion machines from the 1880 s, thanks to the spread of the so-called compound machines, i.e. alternative machines with triple expansion. Such a technical innovation gave a decisive boost to the deep-sea transport of goods by steam vessels. Table 12.1 serves as a first step that compares our results with those of Williams and Armstrong (2012), together with Figure 12.1. Unfortunately, the tonnage capacity of vessels was not reported in the Shipping Index for sailing vessels, and for other years such information had not been kept due to OCR imperfections. One important difference is the measurement unit (tonnage vs. number of calls and vessels). While both time series end up with approximately the same steam dominance (around 97\%), this was already the case as early as 1910 for British ports; however it was not until 1925 when the majority of other ports and regions in the world embraced the change in terms of technological innovation from sail to steam.

\section{[Table 12.1]}

[Figure 12.1]

Our results thus imply strong regional inequalities in relation to this transition, as confirmed by Figure 12.2. Europe as a whole largely surpasses the world average and is very close to the results of Williams and Armstrong (2012) with 93.2\% of steam vessel calls in 1910. Our calculation for British ports even returned a result of $100 \%$ for the same year. The rest of the figure reveals drastic differences among world regions. Asia largely dominates with its much earlier and higher switch to steam over sail during the period 1890-1925, closely followed by Europe and Africa, together constituting a distinct group made up of the "metropolis" and the main "colonial empires". The other group is made up of the Americas and Oceania, which started at much lower levels and went through a much more gradual and slower transition than the previous group, although by 1925 steam shipping was dominant in all regions. The resilience of sail shipping in the second group is explained by the continued economic profitability of specific trade routes and niche markets, such as Australian wheat carried by the so-called "windjammers", nickel and chrome exports from New Caledonia, nitrates from Chile, copper from California as well as grain and lumber from North America's 
West Coast. Favorable winds also to a large extent explain such a regional divergence. Conversely, the state of technological steam in 1890 does not permit shipping with profitability in the South Seas, due to the absence of coal bunkering ports.

[Figure 12.2]

The same analysis is proposed at port level (Figure 12.3) based on the share of sailing vessel traffic in total port traffic, making it possible to confirm the aforementioned trends but at the same time to detect interesting main nodes as well as outliers to such trends. The map for 1890 reveals the high level of steam traffic on the Far East-Europe route via the Suez Canal as well as in the Black Sea, which is one of the first seas where steam power was used at the beginning of the $19^{\text {th }}$ century. As for the Mediterranean and Baltic, the Black Sea is a closed sea which can be easily served by several coal bunkering ports. The significance of the Black Sea steam traffic can be illustrated by the role of Russian steam merchant and military fleets in the ports of Odessa and Sebastopol. In fact, the very low attendance of sailing ships on the Suez Canal route is almost a remarkable exception before 1900. By contrast, as explained above, sail shipping traffic is always significant along the South American coast and on the South Seas routes which are crossed by very fast windjammers. In 1900 and 1905, sail shipping traffic lost ground everywhere except for the American West Coast and Oceanian ports like Australia. The singular situation of Cape Town in 1900, as demonstrated by its exceptional traffic growth, is explained by the Boer War (1899-1900), as the port was used by the British government for debarking troops and as a logistic base for the task force.

The share of sailing traffic decreased quickly after the First World War. A first explanation can be provided by the opening of the Panama Canal in July 1914. This effect may be compared with that of the Suez Canal after 1869 for the Europe-Asia route. With the new Panama Canal, which quickly linked America's west and east coasts, ships could avoid the long and dangerous detour around Cape Horn. Although Buenos Aires was still considered a very important world port at the time, its share of sail shipping traffic remained below $20 \%$ of its total traffic, like most of the other large ports worldwide. Such a global trend is directly attributable to technological progress in relation to engines in the Interwar Period. Indeed, advances in oil-heating technology meant that it was progressively replacing coal as an energy resource for merchant steam vessels. By contrast, the use of diesel technology remained rare in the early 1920s, but witnessed a continuous development during the Interwar Period. Thus, although sail shipping remained very residual in the late period, this analysis shows that it had not yet entirely disappeared in 1925. Such evidence confirms the quality of Lloyd's data and motivates us to visualize in more detail the observed patterns and evolutions by means of more advanced tools.

[Figure 12.3] 


\section{Towards a geovisualization of the sail to steam transition}

\section{Constructing a dedicated geovisualization system}

Visualizing Lloyd's data on the map necessitated the development of a dedicated cartographic website, namely GeoSeastems. Such a tool is currently under development aimed at allowing users to navigate through a cartographic interface, visualize and analyze the database. Yet, such a project relies on a very robust structure. A number of issues had to be overcome during this development, based on the steps described in Figure 12.4.

[Figure 12.4]

Vessel movement data (among ports of the world) do not reveal the exact circulation path of ships (See chapter 10 for a visualization of US seaborne trade data based on a worldwide grid). A grid was therefore constructed to provide an approximation of such paths to map maritime movements while respecting the geographic constraints of territories (Bahoken, 2016). Three approaches were envisaged, depending on the importance given to graphical aspects: the graphical fusion of nodes or linkages (cf. edge bundling), the statistical modeling of maritime trade exchanges, or the cartographic modeling of movements. In theory, this leads us to define how to segment and partition the continuous ocean space where ships circulate. Lloyd's database provides the frequency of vessel calls at and between ports, which had to be assigned to a virtual grid in order to be visualized.

Extracted data from Lloyd's records were stored in a PostGreSQL/PostGIS database. This database is requested by Django, a Python web framework. The Python choice as the principal language of development on the server side (i.e. for the calculation done on the database side) allows the use of numerous libraries specialized in scientific calculation (Numpy) or graph treatment (NetworkX). By opting for this choice, the user is able to visualize different types of statistical or graph-theory based indicators, on chosen data. On the client side (i.e. on the web browser), the results are mapped with OpenLayers and Cesium JavaScript libraries, completed by graphs done with D3.js.

In the first place, ship movements were represented as straight lines, linking the port of departure to port of destination. However, this approach was too schematic to be relevant. The use of a virtual grid was selected, as used by Shen et al. (2013), for instance, and in the Orbis project (Scheidel, 2013), although with a slightly different objective than simply increasing the readability of a statistical flow mapping for the first and displaying dynamics on a website for the second. Specific constraints led us towards another kind of methodology, to avoid handmade corrections following the automated operation and to increase the generic dimension of our method. Handmade operations remain a possible 
option only if the studied area and the expected precision does not imply the creation (or deletion) of too many edges. In the specific case of Lloyd's data, the huge number of port nodes (about 9,000 ) motivated us to fully automatize a process building and control.

Based on "keep it simple" (KISS) methodology, and after the generation of a regular meshing, a network was built using Delaunay triangulation. This first approach was not satisfactory due to the emergence of castellated trajectories on the map and other technical reasons, such as the necessity to increase significantly the number of links near the coastline. This led to an increase in computing time, incompatible with the real-time calculation of trajectories.

The regular meshing was thus improved, by first removing the random component. The idea of a grid with a mixed density of links was kept; but the building itself, with a heterogeneous densification of a simple grid, is fundamentally different. A worldwide meshing was built, composed of 8 squares of $90^{\circ}$ side (Figure 12.5). From this starting element, the meshing was refined with an iterative process. Each square intersecting a continent was subdivided into four same sized squares; those fully included in a continent or an ocean were not divided. Thus, at each iterative step, the number of squares is potentially multiplied by four, as their area is potentially divided by four. This process leads to a refined meshing near coastlines. After several tries, the number of iterations is fixed to seven (this number of iterations having the best ratio between complexity and accuracy). The final meshing is composed of 23,000 squares with areas between $6.10^{3} \mathrm{~km}^{2}$ and $6.10^{6} \mathrm{~km}^{2}$. These are the basis of the grid calculation. A trajectory is considered to be a list of adjacent squares. As the database software used to compute the shortest ways (pgRouting) only works on segments, the list of squares is turned into line strings by linking their respective centroids, using the Moore neighborhood.

The created grid allowed a fluid mapping of trajectories on seas and oceans but did not include river traffic. Thus, it was completed by new links based on Natural Earth physical data. Polygons and lines of lakes and rivers were simplified, to avoid the creation of too many links. River links were then added to the ones previously generated, while the integration of lakes needed an additional step: their median axes were extracted to transform polygons in a set of links.

Once rivers and lakes links were connected to the grid, the final procedure was the creation of links between the grid and the actual position of ports. The first attempt was the linking of each port to the closest node of the grid. However, this solution was not exploitable: the created links were intersecting continents. Closest ports were thus grouped into clusters, and those cluster centroids were linked to the grid. Finally, the links were weighted according to the distance between their two extremities.

[Figure 12.5] 


\section{Geovisualization results}

The new maps can be considered as the first-ever visualizations of world maritime trade flows in the late $19^{\text {th }}$ and early $20^{\text {th }}$ century (Figures 12.6 to 12.9 ). Although they confirm a number of trends already observed in previous figures, they also show more clearly a number of elements, as explained in the following, based on one map every 10 years since 1890. In that year, the Europe-Mediterranean-Far East route appears already dominated by steam shipping. As expressed by Fletcher (1958), "the Suez Canal became, nearly without exception, the route of all-steaming". The main advantage offered by the canal resided logically in the reduced deviation distance for ships. The voyage between Liverpool and Bombay was reduced by $42 \%$ and to Singapore by $30 \%$. Moreover, the multiplicity of coal stations on the way permitted an increased loading capacity for freight. Up to 1910, the Indian Ocean-Australia line still exhibited the relative importance of sail shipping, as was the case with the Atlantic-to-Pacific route around Latin America.

Lines still dominated by sail shipping, in particular the routes of the southern seas sailed by windjammers, were global circumnavigation routes connecting the three main capes of the southern hemisphere (Horn, Good Hope, and Leeuwin). Elsewhere, certain routes were peripheral on the map but carried vital raw materials for the world economy. This was the case, for instance, of the coal exchange from Europe to the Antipodes, which, in turn, exported ores and minerals (nitrate, nickel, copper, etc.). A mixed-use area was the Atlantic itself. In particular, the Europe-Argentina route was characterized by the lack of coal stations and the profitability for certain types of cargo carried by steam ships. The same applied to the Europe-Caribbean route. However, such a result is particularly surprising for the North Atlantic routes between Europe and North America. In 1890, liners transporting migrants and travelers were all using steam. The relatively important presence of sail shipping can thus be explained by cargo shipping, here also for profitability reasons.

[Figure 12.6]

[Figure 12.7]

Between 1900 and 1920, from a European-centered core (Atlantic and Mediterranean), steam navigation becomes gradually hegemonic along the world's busiest sea lanes: EuropeSuez-Far East, North Atlantic, and South Atlantic. The center of the Atlantic resists against the invasion of steam, certainly due to the lesser profitability of such routes. After the First World War, the southern seas and the Pacific, sailed by secondary routes, remain the last areas still reached by sail merchant shipping. In the case of Australian wheat exports, 
Australian ports remain poorly accessible and less than financially favorable to large capacity steamers (Lenhof, 2005).

[Figure 12.8]

[Figure 12.9]

\section{Conclusion}

This chapter is innovational at several levels. Here, for the first time global vessel movement data is condensed, distinguishing sail from steam shipping, in order to broach one of the most important debates in maritime and economic history on technological transitions. Secondly, and in order to reach such a goal, it mobilized a full circle of cartographical and geomatics competencies and knowledge, giving birth to a new geovisualization tool dedicated to mapping vessel movement data. Thirdly, via these two elements our research managed to produce the first-ever maps of global maritime trade in the 1890-1925 period. Such advances contribute both to economic history and cartographic science. Our main results confirmed a considerable amount of acquired knowledge on the evolution of world shipping, but also delivered novel findings. Our quantification of sail versus steam importance, which was previously based on British port traffic only, contributed toward questioning the rapidity of this technological transition. In addition, it provided the muchoverlooked geographic dimension of technological change, at the level of continents, routes, and ports.

Further research shall be led in several ways. The refinement of cartography first should concentrate on refining the mesh refining during the maritime grid development, such as by taking into account, during the mesh subdivision step, not only continents but also the situation of ports. Such a procedure would allow reducing the number of edges in lowfrequency coastal areas. In addition, the aggregation of nodes at the level of larger spatial units such as maritime ranges would improve the readability of the maps, by avoiding the multiplication of low-capacity linkages across the ocean-space. The use of color and other aesthetical features, with the ultimate goal to provide an open source and open access online webmapping tool, will offer more possibilities. Another research pathway is the additional extraction of Shipping Index items to obtain a fuller time-series database that would be more representative of yearly trends, from 1880 onwards. Such a database could be extended to later years in order to map and analyze other technological transitions, such as from steam to combustion (Diesel engines), vessel specialization, of which the container revolution, up to the current era of mega-ships. This would help us to compare the spatial 
dynamics of each transition, in terms of geographic distribution and pace, given that earlier works found noticeable resemblance between past and current mechanisms of port competition in times of technological progress (Marnot, 2005). We also should better understand the emergence and diffusion of containerization, a wide research area where quantitative investigations remained bound to country-level data (Bernhofen et al., 2013) or container port throughout data (Guerrero and Rodrigue, 2014), thus missing the relational and multi-commodity perspectives offered by Lloyd's shipping flows. Beyond the description of technological change, such efforts shall lean towards a confrontation to classic models about the spatial diffusion of innovations (Hägerstrand, 1952) but also to wider models of diffusion and propagation in networks (Valente, 1996).

\section{Acknowledgements}

The research leading to these results has received funding from the European Research Council under the European Union's Seventh Framework Programme (FP/2007-2013) / ERC Grant Agreement n. [313847] "World Seastems".

\section{References}

Bahoken F. (2016) Contribution à la Cartographie d'une Matrice de Flux. PhD Dissertation in Geography, University of Paris Diderot - Paris 7.

Bahoken F., Grasland C., Zanin C. (2016) D'une cartographie de flux à une cartographie du mouvement spatial, aspects sémiologiques. Paper presented at the Colloque Temps, Art et Cartographie (TAC2016), Comité Français de Cartographie (CFC), Strasbourg, France, March 16-18.

Bahoken F., Lagesse C., Ducruet, C. (2016) L'approche cartographique de la représentation du mouvement spatial. L'exemple des flux commerciaux maritimes euro-méditerranéens. Proceedings of the SAGEO'2016 Conference, Nice, 6-9 December.

Bernhofen D.M., El-Sahli Z., Kneller R. (2013) Estimating the Effects of the Container Revolution on World Trade. Lund University Working Paper 2013:4, Department of Economics, School of Economics and Management.

Bertin J. (1973) Sémiologie Graphique. Paris: Mouton-Gauthier-Villars. 
Bretagnolle A. (2005) De la théorie à la carte: histoire des représentations géographiques de I'espace-temps. In: Volvey A. (Ed.), Echelles et Temporalités. Paris: Atlande, pp. 55-60.

Bretagnolle A. (2009) Villes et Réseaux de Transport: des Interactions dans la Longue Durée (France, Europe, Etats-Unis). Habilitation à Diriger des Recherches, University of Paris 1 Panthéon-Sorbonne.

Buard E., Devogele T., Ducruet C. (2015) Trajectoires des objets mobiles dans un espace support fixe. Revue Internationale de Géomatique, 25(3): 331-354.

Ducruet C. (2015) Maritime flows and networks in a multidisciplinary perspective. In: Ducruet C. (Ed.), Maritime Networks: Spatial Structures and Time Dynamics, London and New York: Routledge Studies in Transport Analysis, pp. 3-26.

Ducruet C. (2016) The Spatiality of Maritime Networks: Maritime Contributions to the Analysis of Networks in Geography. Paris: University of Paris I Panthéon-Sorbonne (in French).

Ducruet C., Marnot B. (2016) Analyser les trafics portuaires mondiaux en 1890 et en 1925 à partir des registres du Lloyd's, In: GIS d'Histoire Maritime (Ed.), La Maritimisation du Monde de la Préhistoire à nos Jours, Paris: Presses Universitaires de Paris-Sorbonne, pp. 383-398.

Etienne L., Alincourt E., Devogele T. (2015) Maritime network monitoring: From position sensors to shipping patterns. In: Ducruet C. (Ed.), Maritime Networks: Spatial Structures and Time Dynamics, London and New York: Routledge Studies in Transport Analysis, pp. 190-209.

Fletcher M.E. (1958) The Suez Canal and world shipping, 1869-1914. The Journal of Economic History, 28: 558.

Goodchild M.F., Yuan M., Covas J.T. (2007) Towards a general theory of geographic representation in GIS. International Journal of Geographic Information Science, 21(3): 239260.

Grataloup C. (2011) Représenter le Monde. La Documentation Française, La Documentation photographique - Les dossiers, No. 8084.

Guerrero D., Rodrigue J.P. (2014) The waves of containerization: shifts in global maritime transportation. Journal of Transport Geography, 34: 151-164.

Hägerstrand T. (1952) The Propagation of Innovation Waves. Lund, Sweden: Royal University of Lund, Lund Studies in Geography. 
L'Hostis A. (1997) Représentation en relief des réseaux de transport de l'arc atlantique: déformations de l'espace-temps en "vallées " et " montagnes ". Actes du colloque TheoQuant, pp. 107-112.

L'Hostis A. (2014) Le Détour, la Pause et l'Optimalité. Essai sur la Distance et ses Apports au Transport et à I'Urbanisme. Habilitation à Diriger des Recherches, Université Paris-EstMarne-la-Vallée, LVMT, IFSTTAR.

Lehnof J.L. (2005) Les Hommes en Mer. De Trafalgar au Vendée Globe. Paris: Armand Colin.

Marnot B. (2005) Interconnexion et reclassements: I'insertion des ports français dans la chaîne multimodale au XIXe siècle. Flux, 59(1): 10-21.

Müller J.C. (1979) La cartographie d'une métrique non euclidienne: les distances-temps. L'Espace Géographique, 3: 215-227.

Rodrigue J.P., Comtois C., Slack B. (2013) The Geography of Transport Systems. London and New York: Routledge.

Scheidel W. (2013) The Shape of the Roman World. Working Paper, Stanford University.

Siegfried A. (1940) Suez, Panama et les Routes Maritimes Mondiales. Paris: Armand Colin.

Tobler W.R. (1979) Estimations of attractivities from interactions. Environment and Planning A, 11: 121-127.

Ullman E.L. (1949) Mapping the world's ocean trade: A research proposal. The Professional Geographer, 1(2): 19-22.

Valente T.W. (1996) Social network thresholds in the diffusion of innovations. Social Networks, 18(1): 69-89.

Williams D.M., Armstrong J. (2012) An appraisal of the progress of the steamship in the nineteenth century. In: Harlaftis G., Tenold S., Valdaliso J.M. (Eds.), The World's Key Industry, Palgrave Macmillan UK, pp. 43-63. 


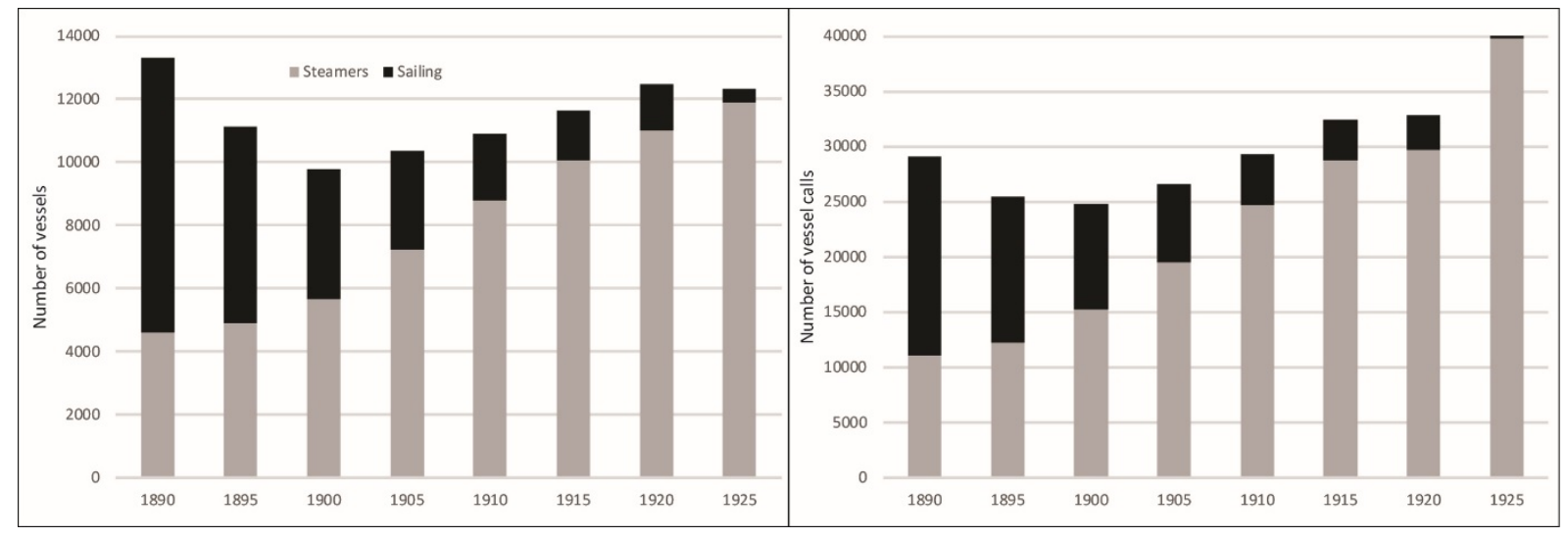

Figure 12.1: Evolution of sail and steam fleet and traffic size, 1890-1925

Source: own elaboration based on Lloyd's List data

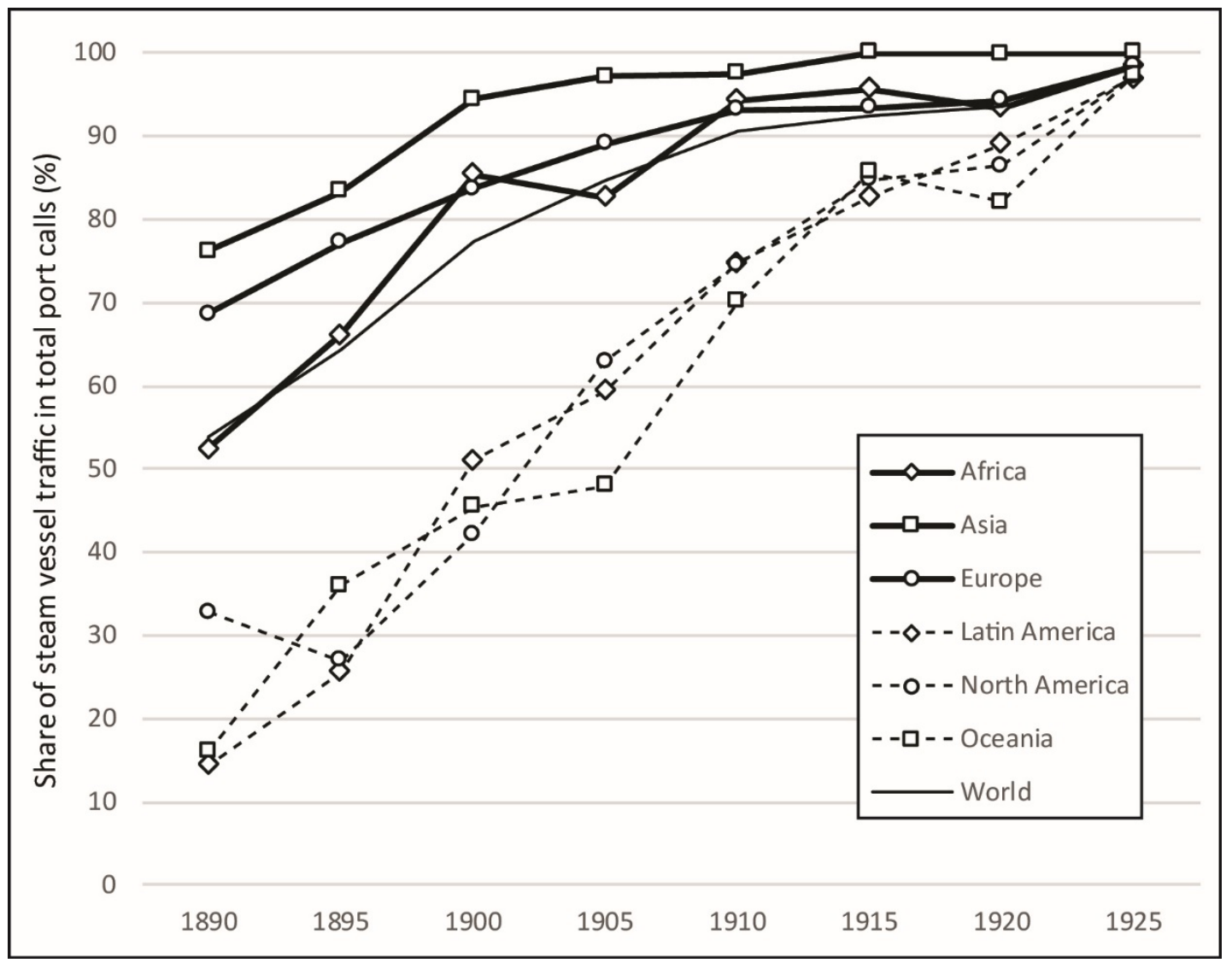

Figure 12.2: Sail to steam traffic evolution by world region, 1890-1925

Source: own elaboration based on Lloyd's List data 

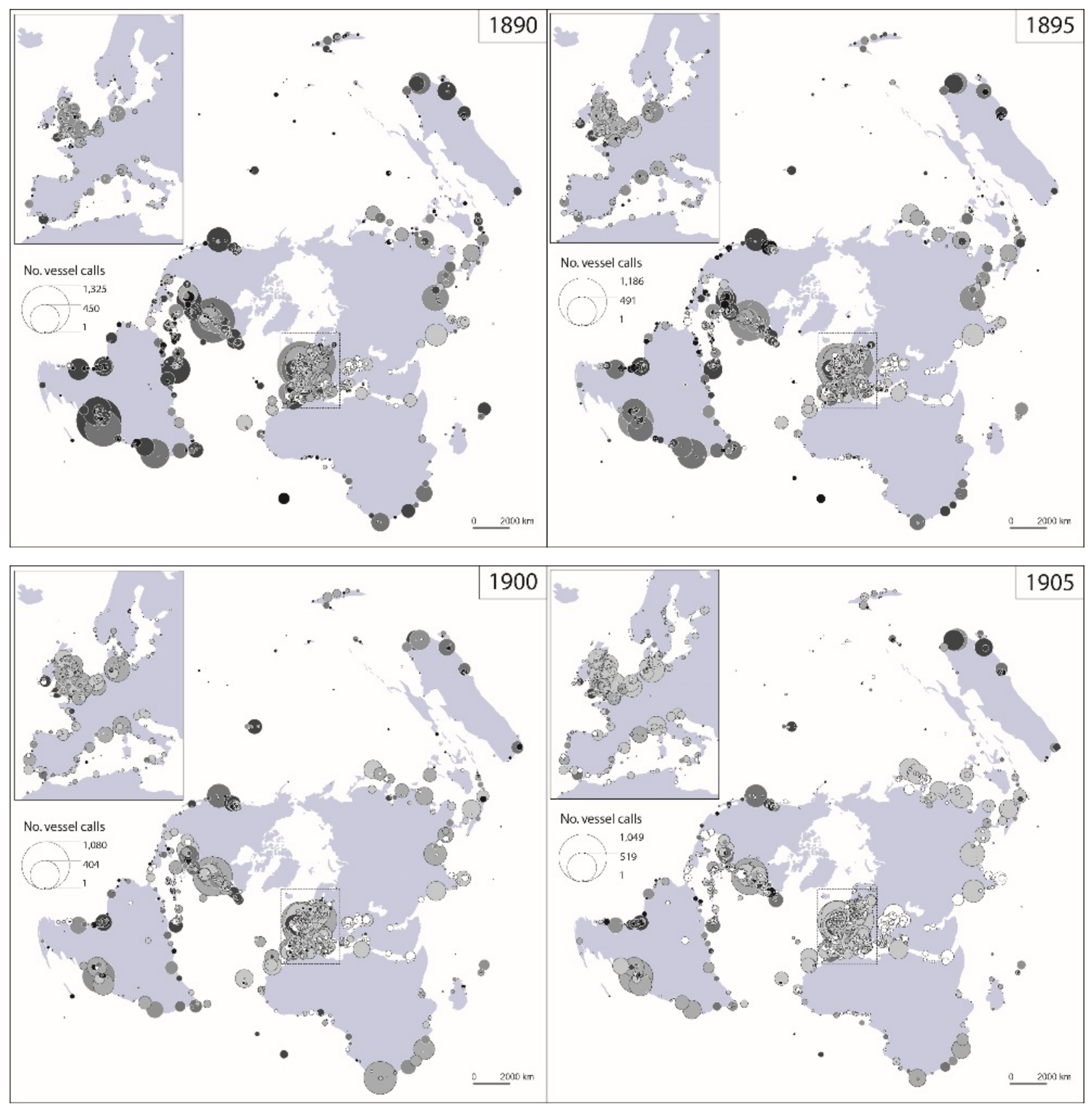

Figure 12.3: Spatial distribution of sail shipping traffic among world ports, 1890-1925

Source: own elaboration based on Lloyd's List data 

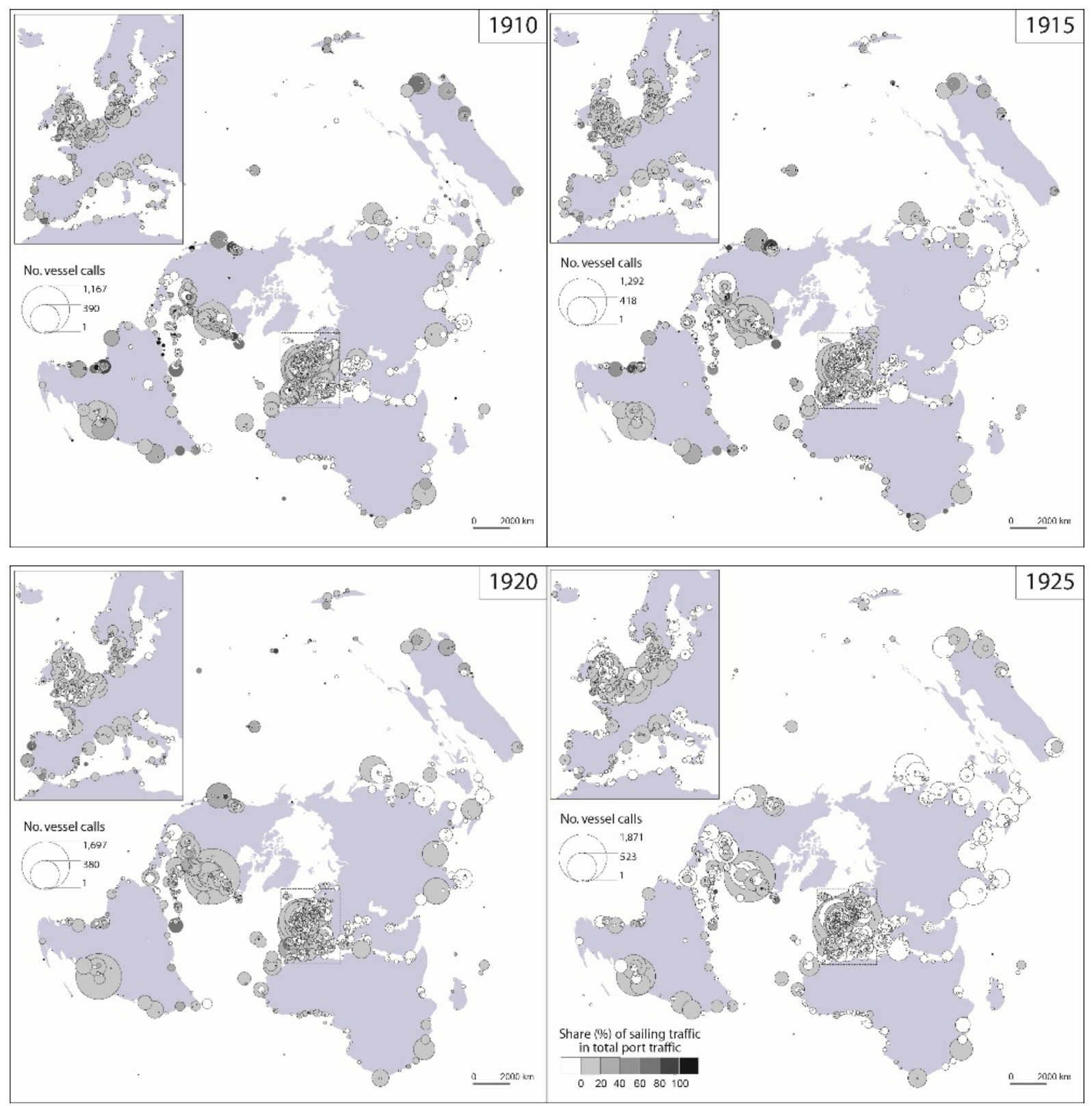

(continued) 


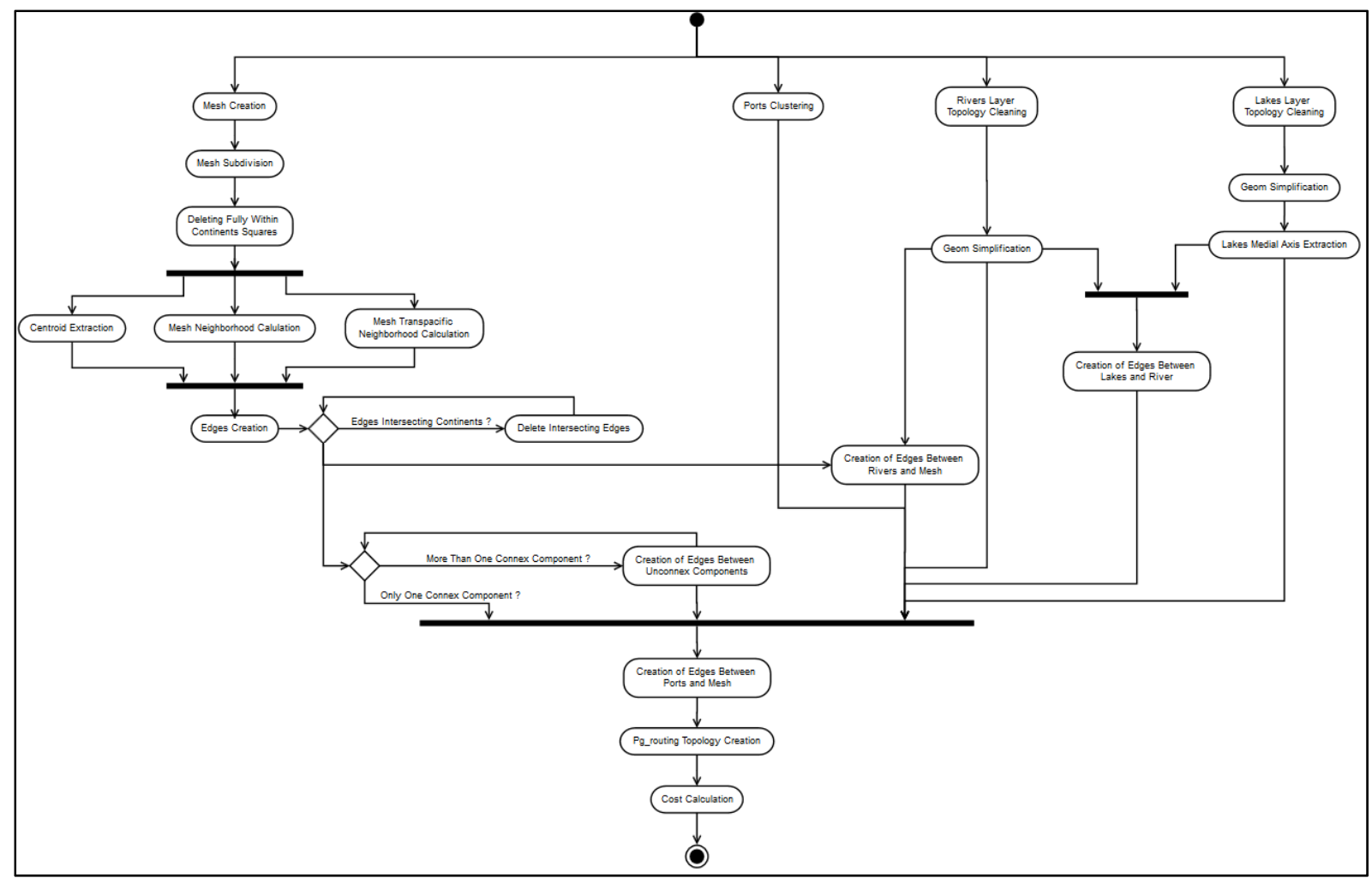

Figure 12.4: Data conceptual model

Source: own elaboration

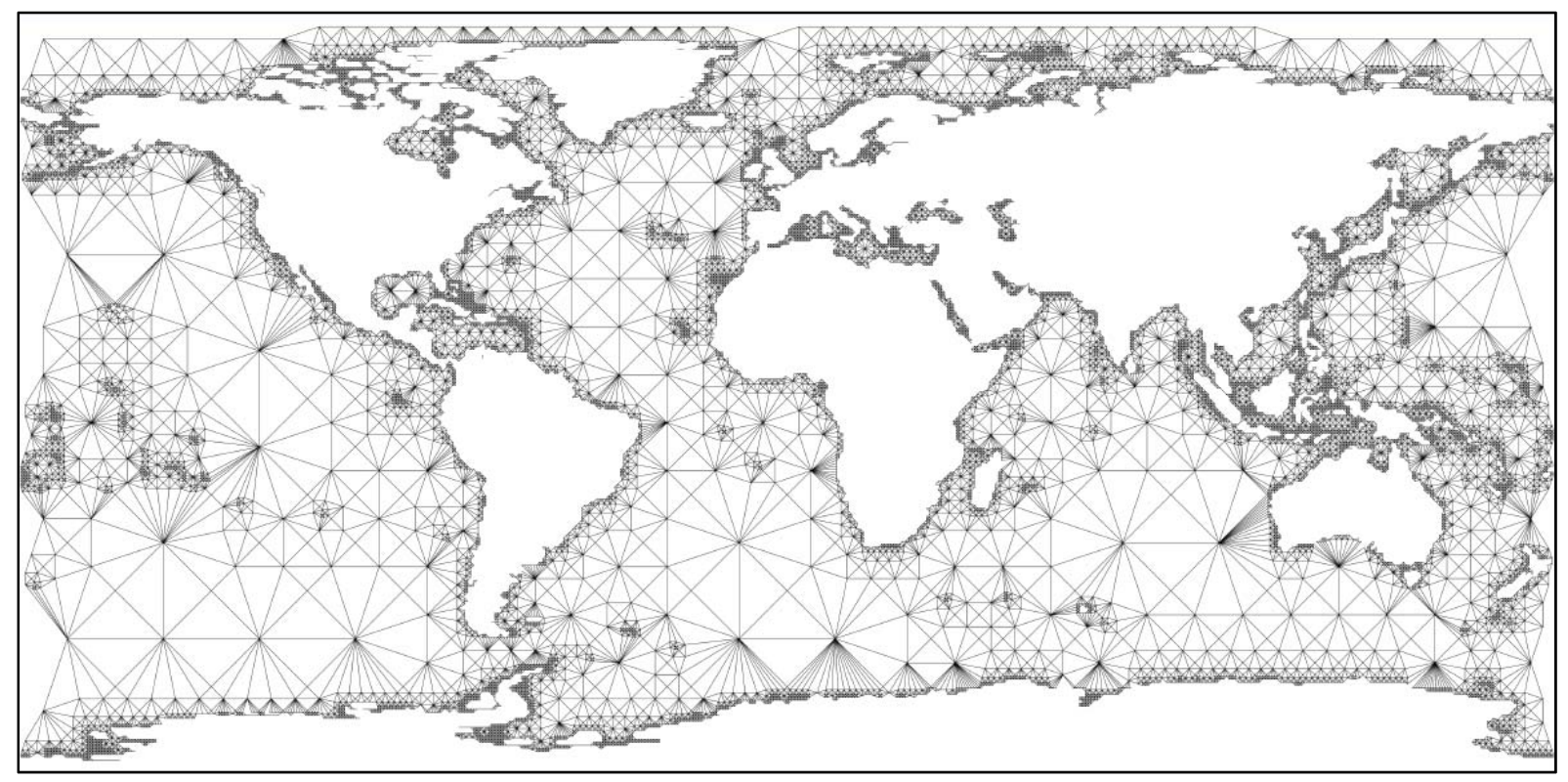

Figure 12.5: The world maritime grid

Source: own elaboration 


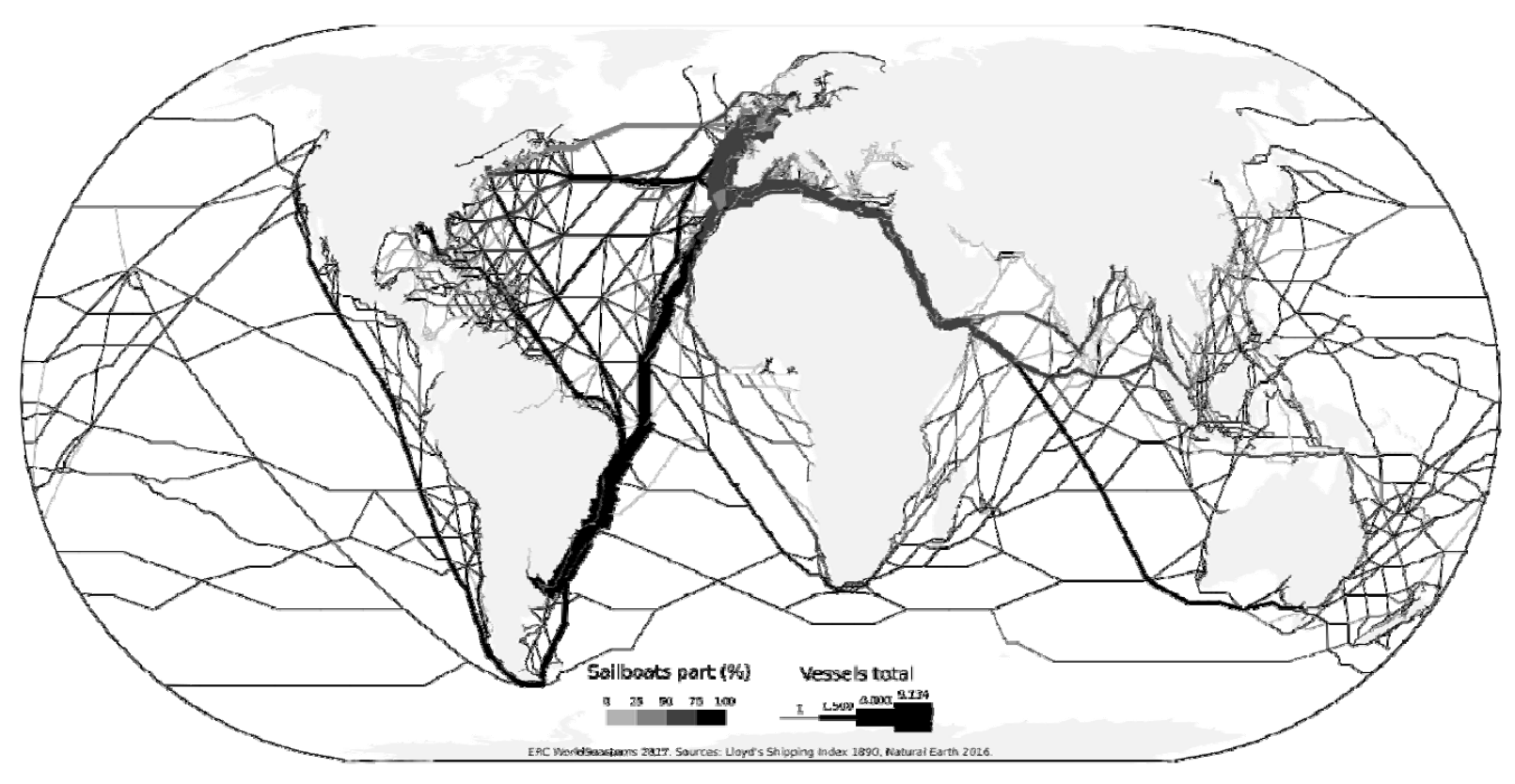

Figure 12.6: World maritime flows, 1890

Source: own elaboration based on Lloyd's List data

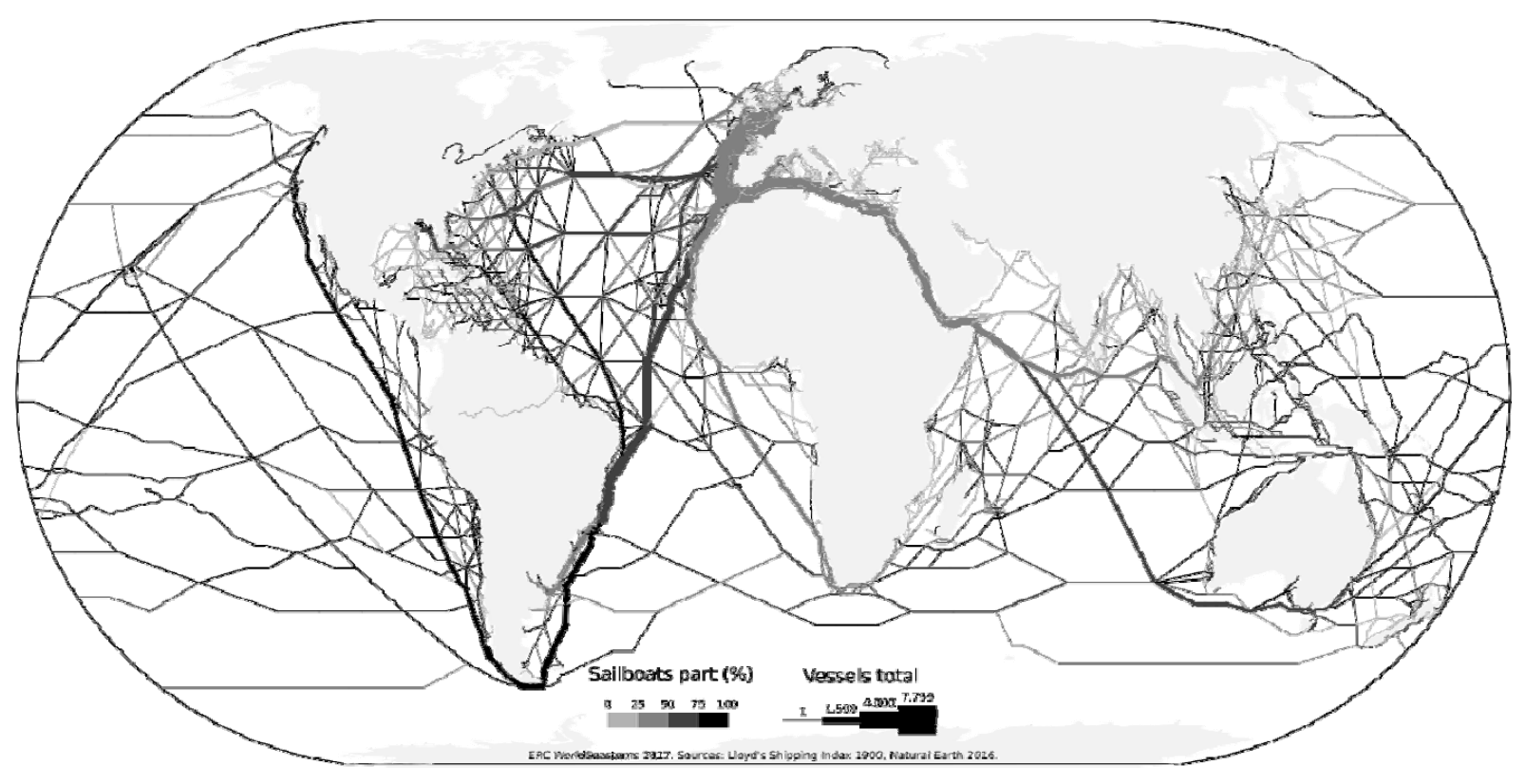

Figure 12.7: World maritime flows, 1900

Source: own elaboration based on Lloyd's List data 


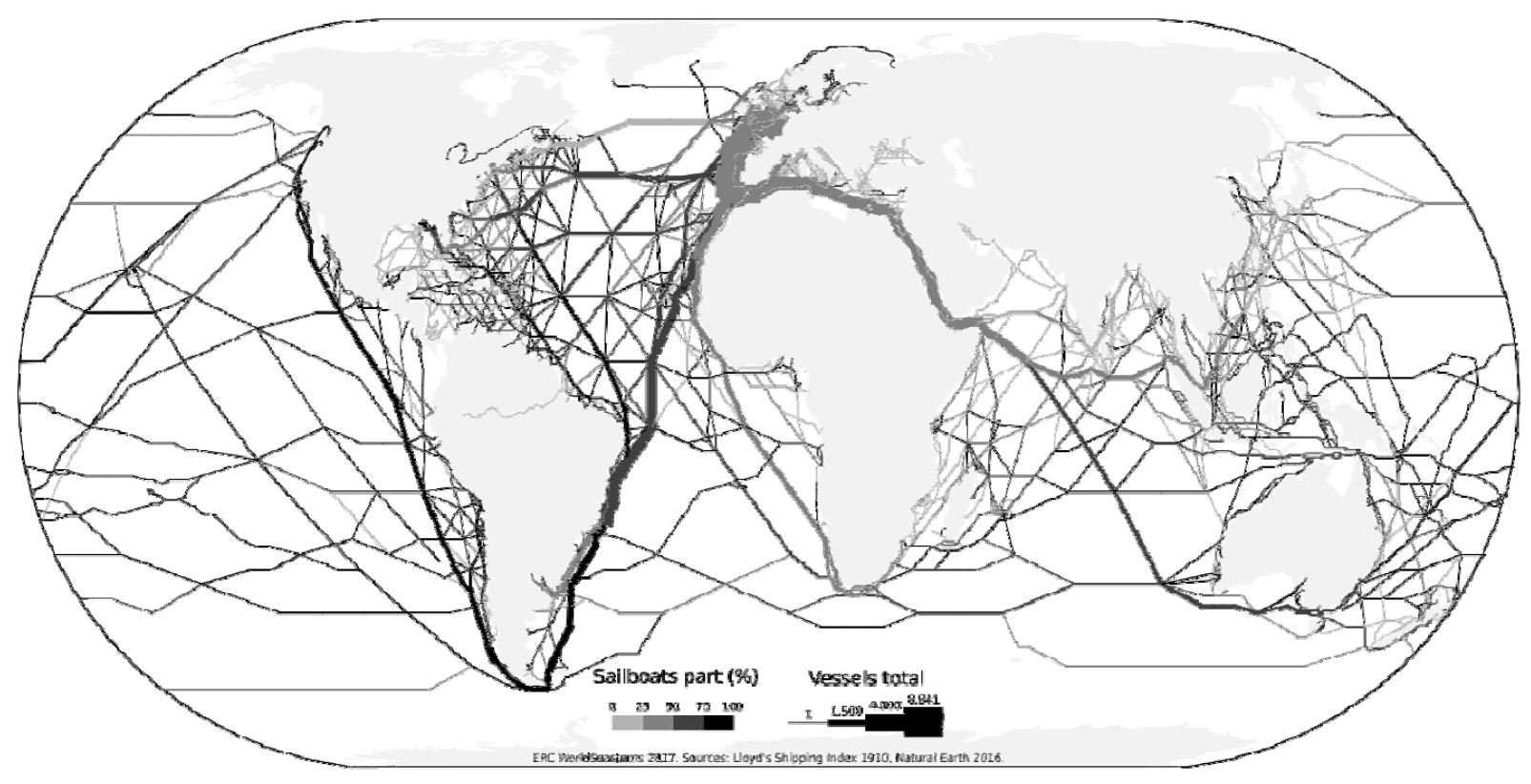

Figure 12.8: World maritime flows, 1910

Source: own elaboration based on Lloyd's List data

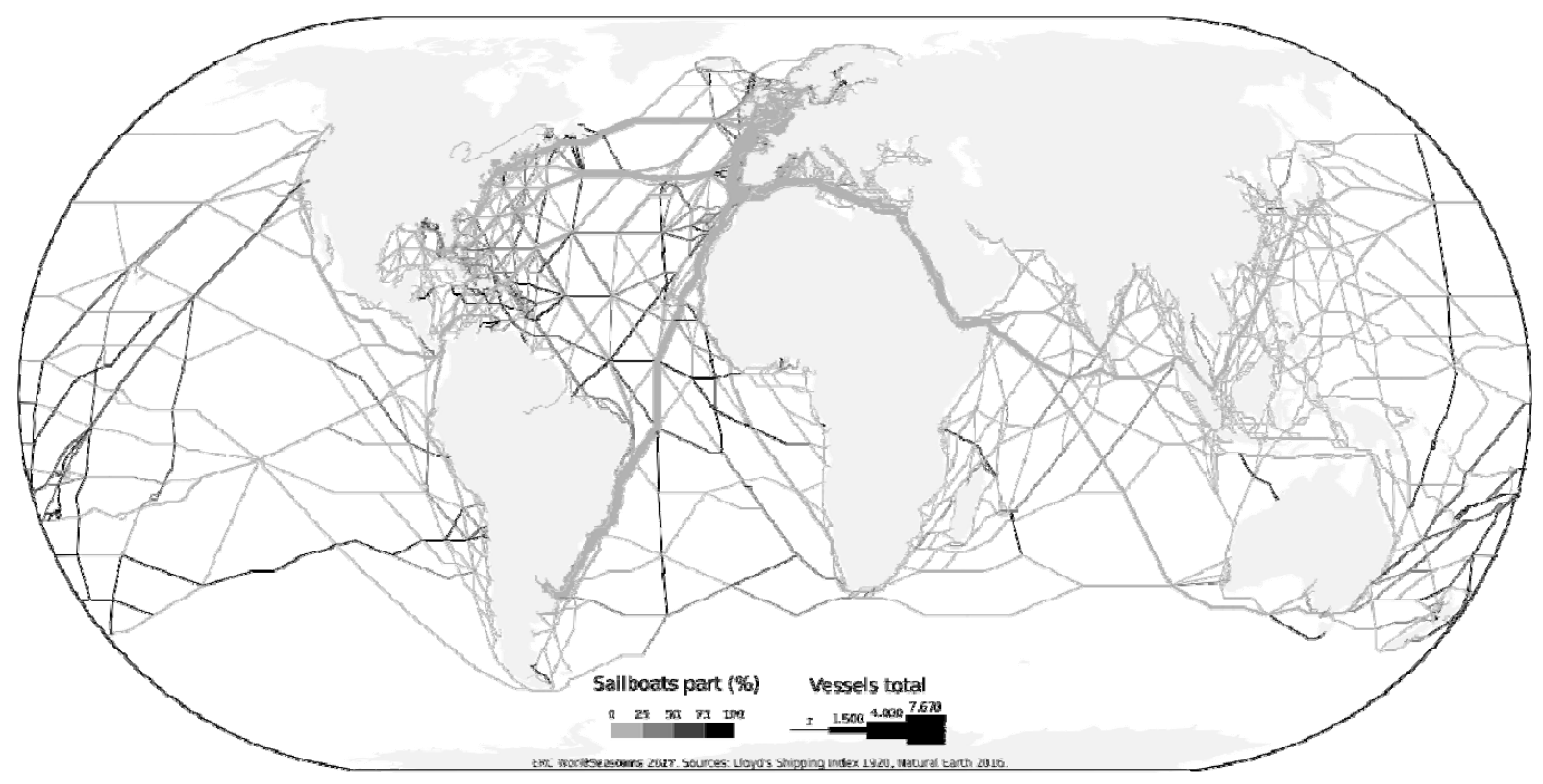

Figure 12.9: World maritime flows, 1920

Source: own elaboration based on Lloyd's List data 


\begin{tabular}{|c|c|c|c|c|}
\hline \multirow[b]{2}{*}{ Year } & \multicolumn{2}{|c|}{ British ports* } & \multicolumn{2}{|c|}{ World ports** } \\
\hline & $\begin{array}{l}\text { Entrances with } \\
\text { cargo and in } \\
\text { ballast (\% } \\
\text { tonnage) }\end{array}$ & $\begin{array}{l}\text { Entrances with } \\
\text { cargo and in } \\
\text { ballast (\% } \\
\text { vessels) }\end{array}$ & $\begin{array}{c}\text { Number of } \\
\text { vessels (\% } \\
\text { vessels) }\end{array}$ & $\begin{array}{c}\text { Number of } \\
\text { calls (\% } \\
\text { calls) }\end{array}$ \\
\hline 1855 & 15.8 & 12.4 & - & - \\
\hline 1860 & 20.9 & 15.5 & - & - \\
\hline 1870 & 33.8 & 22.8 & - & - \\
\hline 1880 & 63.0 & 47.0 & - & - \\
\hline 1890 & 82.8 & 69.8 & 34.7 & 38.2 \\
\hline 1900 & 91.8 & 81.4 & 57.7 & 61.6 \\
\hline 1910 & 97.1 & 90.5 & 80.8 & 84.6 \\
\hline 1920 & - & - & 88.2 & 90.4 \\
\hline 1925 & - & - & 96.5 & 98.3 \\
\hline
\end{tabular}

Table 12.1: Share of steamer fleet and traffic by data source, 1855-1925 Source: adapted from Williams and Armstrong (2012)* and Lloyd's List data** 